\title{
ANÁLISE DE ENVOLTÓRIO DE DADOS (DEA) COMO INSTRUMENTO DE TOMADA DE DECISÃO NA EMPRESA "Y" DO RAMO DE ELETROMAGAZINE
}

\section{ARTIGO ORIGINAL}

PIMENTEL, Carla Jamile Soares ${ }^{1}$

ALMEIDA, João Batista De França ${ }^{2}$

ARAÚJO, Jamille Carla Oliveira ${ }^{3}$

Ó, Marco Aurelio Alves Leal do ${ }^{4}$

PIMENTEL, Carla Jamile Soares. Et al. Análise de Envoltório de Dados (DEA) como instrumento de tomada de decisão na Empresa "Y" do ramo de Eletromagazine. Revista Científica Multidisciplinar Núcleo do Conhecimento. Ano 04, Ed. 10, Vol. 06, pp. 102-130. Outubro de 2019. ISSN: 2448-0959, Link de acesso: https://www.nucleodoconhecimento.com.br/administracao/analise-deenvoltorio

\section{RESUMO}

Pretende-se, com este trabalho, analisar os dados relacionados ao envoltório de dados (conhecido por DEA) por meio do processo de Análises dos Demonstrativos

${ }^{1}$ Discente do curso de Administração da Universidade Federal Rural da Amazônia (UFRA).

${ }^{2}$ Discente do curso de Administração da Universidade Federal Rural da Amazônia (UFRA).

${ }^{3}$ Mestre em Administração, MBA Gestão contábil, perícia, auditoria e controlaria, Bacharel em Ciências Contábeis.

4 Doutorando em ciências Contábeis FUCAPE, Mestre em Administração, MBA Gestão contábil, perícia, auditoria e controlaria, Bacharel em Ciências Contábeis. 
Contábeis, pois esse é um instrumento para a tomada de decisão na Empresa "Y" a partir da análise da situação econômica e financeira por meio de índices. Propõe-se, dessa forma, uma pesquisa de caráter qualitativo e descritivo para, por meio do DEA, realizar as análises dos demonstrativos contábeis, conforme recomenda a literatura. Esse tipo de procedimento diverge das pesquisas quantitativas pois tem como objetivo valorizar e viabilizar a visão/perspectiva dos agentes sociais. A aplicabilidade deste estudo se voltou à uma empresa que foi denominada de " $Y$ ". A entidade escolhida possui sede em Capanema, no Pará. O seu ramo de atuação é o setor do comércio varejista especializado, principalmente, em eletrodomésticos, móveis, artigos de vestuário e acessórios e em equipamentos de áudio e vídeo. A partir da análise, percebeu-se que a análise financeira e econômica possibilita uma melhor visualização do percentual e do o nível de dependência de capital de terceiros financiando de cada conta em relação ao total do qual faz parte, ou seja, permite verificar se a empresa consegue arcar com suas obrigações de curto e longo prazo bem como com a ociosidade dos estoques, para, dessa forma, aderir a um controle gerencial mais efetivo para cada conta perante as necessidades e planejamento da organização. Com a análise, foi possível notar que a empresa " $Y$ " se revelou como ineficiente, pois não consegue cumprir com suas obrigações para com os credores, sobretudo quando não há uma redução significativa do estoque. Refletir sobre a DEA aplicada ao processo de tomada de decisão é relevante pois torna possível afirmar se uma dada entidade é eficiente ou não.

Palavras chaves: Análise de Envoltório de Dados (DEA), Demonstrativos Contábeis, Eficiência.

\section{INTRODUÇÃO}

A análise da eficiência das empresas é um procedimento necessário porque serve tanto à fins estratégicos, voltados, principalmente, às comparações financeiras, quanto para processos direcionados ao planejamento, sobretudo para a realização de avaliações quanto aos resultados relacionados ao uso, e, também, auxilia nos processos de tomada de decisão, principalmente aquelas que envolvem a proposição e otimização do desempenho gerencial (GOMES; MANGABEIRA; MELLO, 2005; 
PIMENTEL; ALMEIDA, 2009; SANTOS; CASA NOVA, 2005). Tais abordagens caminham para o desenvolvimento de uma análise das demonstrações financeiras, não visando, apenas, refletir sobre os investimentos dessas organizações, pois se objetiva, também, discutir e verificar a insolvência empresarial (CASA NOVA, 2002, 2005).

Percebe-se, no entanto, que as demonstrações contábeis que são, usualmente, divulgadas pelas empresas, acabam se tornando objeto de pesquisa de alguns autores, como, por exemplo, de Kassai (2002) e de Santos e Casa Nova (2005). Assim, torna-se necessário avaliar os indicadores contábeis que se manifestam nos balanços fornecidos pelas empresas, e, dessa forma, não se trata, apenas, de um contexto da informação contábil, mas da qualidade e da interpretação dos fenômenos econômicos e financeiros das entidades (SANTOS; CASA NOVA, 2005; DALMOLIN et al, 2012; PIMENTEL; ALMEIDA, 2019; OLIVEIRA et al, 2010). Torna-se necessário, ainda, discorrer sobre as inferências que são feitas sobre as tendências futuras, pois visa-se, sempre, atender os próprios objetivos da empresa (KASSAI, 2002, IUDICIBUS, 2008, OLIVEIRA; SILVA; ZUCCARI, 2010).

De acordo com Silva (1997), a primeira ferramenta de avaliação utilizada para a análise das demonstrações contábeis tomou forma a partir do estudo de Fitz Patrick, publicado no ano de 1932. O autor confrontou, de maneira aleatória, 19 empresas que declararam falência no período de 1920 a 1929. Essas foram comparadas com outras 19 entidades bem-sucedidas. Para a execução dessa análise, recomenda-se o modelo de Altman (1968), pois é o mais famoso. Este foi o primeiro a fazer o uso discriminante da análise para determinar uma equação capaz de avaliar a probabilidade de insolvência de empresas. Permeado por tal necessidade, criou-se o modelo de previsão de falências (PIMENTEL; ALMEIDA, 2019; SANTOS; CASA NOVA, 2005). Após esse, houve estudos de composição de modelos de avaliação de análise de balanços com o propósito de prever a probabilidade de falência. Um exemplo é o "Termômetro das Insolvências" (KANITZ, 1974).

Contudo, ressalta-se, aqui, que outras metodologias são igualmente importantes para a realização deste tipo de análise, como a estatística de regressão, as análises 
fatoriais, as análises discriminantes, etc. (Matias e Siqueira, 1996). Além disso, o estudo caminhou no cerne da DEA por meio da análise como um todo dos demonstrativos contábeis, sobretudo para estabelecer um diagnóstico sobre o desempenho organizacional, e, assim, traz uma visão mais holística do negócio, do contexto organizacional e da cultura. A pesquisa foi executada dentro e fora do ambiente. Percebeu-se que os estudos de DEA ainda são bastante recentes, e, dessa forma, pouco explorados, de acordo com Casa Nova (2010). Os trabalhos existentes, de forma geral, costumam comparar os resultados econômicos bem como aderem à modelos tradicionais voltados à análise empresarial, e, assim, são construídos com base em análises de regressão ou discriminantes. Detectou-se, também, que a maioria dos trabalhos discorrem sobre grandes empresas situadas no Sudeste do país (PIMENTEL; ALMEIDA, 2019).

Desta forma, o estudo é relevante pois serve modelo de avaliação para outros empreendimentos locais. Além do mais, ainda não se realizou estudos nesta proporção em organizações paraenses. Um senso a isto é o fato de muitas organizações paraenses, apresentarem problemas nos demonstrativos contábeis disponíveis para consulta na Junta Comercial do Estado do Pará (ARAÚJO; CRUZ, 2018). Percebe-se que a fidedignidade das informações para a extração de demonstrativos que não sejam tão próximos do exercício atual bem como a presença de um pesquisador no ambiente empresarial são práticas importantes. Nesse sentido, o objetivo geral da pesquisa é: aplicar a análise de envoltório de dados (DEA) por meio das Análises dos Demonstrativos Contábeis como instrumento para tomada de decisão na Empresa "Y". Parte-se do princípio de que a DEA influencia, diretamente, neste processo assim como nos resultados. Dessa forma, o estudo pretende extrair respostas para o seguinte problema de pesquisa: como a "Análise por resultados" (DEA) como instrumento para Tomada de Decisão em uma empresa "Y" do comércio de Capanema/PA? 


\section{REFERENCIAL TEÓRICO}

\section{ANÁLISE DOS DEMONSTRATIVOS CONTÁBEIS}

Para Pereira (2013), a análise das demonstrações contábeis (DEA) é uma ferramenta da área da contabilidade que tem como objetivo obter informações relacionadas a situação de uma determinada empresa. Esses dados podem ser positivos ou negativos. Neste contexto, o Conselho Federal de Contabilidade - CFC, a partir da resolução 1.121 de 2008, definiu as quatro principais características qualitativas para a execução das Demonstrações Contábeis, são elas: compreensibilidade, relevância, comparabilidade e confiabilidade (PIMENTEL; ALMEIDA, 2019; SILVA et al, 2016; OLIVEIRA et al, 2010).

Quadro 1: Características qualitativas das demonstrações contábeis

\begin{tabular}{|l|l|}
\hline Caraterísticas & Abordagem \\
\hline Compreensibilidade & $\begin{array}{l}\text { Uma qualidade essencial das informações apresentadas nas } \\
\text { demonstrações contábeis é que elas sejam prontamente } \\
\text { entendidas pelos usuários. }\end{array}$ \\
\hline Relevância & $\begin{array}{l}\text { Para serem úteis, as informações devem ser relevantes às } \\
\text { necessidades dos usuários na tomada de decisões. }\end{array}$ \\
\hline Comparabilidade & $\begin{array}{l}\text { Os usuários devem poder comparar as demonstrações } \\
\text { contábeis de uma entidade ao longo do tempo, a fim de } \\
\text { identificar tendências na sua posição patrimonial e financeira } \\
\text { e no seu desempenho. }\end{array}$ \\
\hline $\begin{array}{l}\text { Para ser útil, a informação deve ser confiável, ou seja, deve } \\
\text { estar livre de erros ou vieses relevantes e representar } \\
\text { adequadamente aquilo que se propõe a representar. }\end{array}$
\end{tabular}

Fonte: CFC (2008).

Para Silva (2014) e Pimentel e Almeida (2019), essas características possibilitam a realização de comparações entre tendências regionais, ou, ainda, entre segmentos 
nos quais a empresa se encontra inserida. Dessa forma, determina-se, também, as perspectivas futuras voltadas à rentabilidade bem como à continuidade dos negócios. Possibilita, ainda, aos gestores dessas empresas, a tomada de decisões mais eficientes frente aos investimentos e financiamentos bem como em relação à implementação de mudanças de atitudes, caso essas tendências enfatizem que a empresa está inserida em um cenário não condizente para com as políticas, metas e objetivos organizacionais traçados. Pode, até mesmo, conduzir um determinado estabelecimento à novos rumos.

Salvador (2011), em seu estudo, enfatiza que é fundamental, dentro de uma organização, que os problemas de gestão sejam detectados para o estabelecimento de estratégias coerentes. A partir da detecção desses problemas, deve-se buscar por soluções efetivas por meio da Análise das Demonstrações Contábeis. É uma ferramenta recomendável pois fornece informações aos gestores sobre os mais diversos assuntos relacionados à empresa. O conteúdo dessa análise é de origem econômica e financeira. O principal objetivo é fazer com que essas informações sejam utilizadas de maneira segura e adequada bem como precisam ser de fácil.compreensão aos administrados (SANTOS; CASA NOVA, 2005; HANAOKA; LEON, 2017; PIMENTEL; ALMEIDA, 2019).

Desta forma, a contabilidade dispõe de ferramentas que são estruturadas para possibilitar a formação de um diagnóstico perante a situação econômica financeira das empresas (matarazzo,2010). Para Hanaoka e Leon (2013), um dos instrumentos mais essenciais que deve fazer parte das organizações é a contabilidade. Ela fornece informações tanto de eventos passados quanto realiza previsões futuras para que um gestor possa tomar decisões de forma mais apropriada e segura. Assim sendo, as demonstrações contábeis são importantes pois fornecem um panorama geral sobre a situação do passado e do presente de uma dada entidade. Nesse sentido, torna-se possível obter dados para que o planejamento futuro dessa empresa resulte em um bom desempenho. Essas informações contábeis derivam de modelos que orientam os investidores e credores. É conhecido como Análise de Demonstrações Contábeis. 
Outros estudos, como o de Santos e Casa Nova (2005) e o de Oliveira et al (2010), entendem que este tipo de análise é muito mais do que o acionamento de técnicas para a análise de balanços. Entendem que esse processo é uma arte. Destarte, construiu-se indicadores voltados à previsão da insolvência com base em instrumentos quantitativos sofisticados (SILVA et al, 2010). Popularmente, são conhecidos como modelos estatísticos que preveem a insolvência. A partir dos dados levantados pela Análise das Demonstrações Contábeis, os gestores conseguem visualizar, de forma mais abrangente, a situação e a evolução da empresa. Conseguem, ainda, ver a sua posição no mercado em relação aos concorrentes por meio da comparação dos seus índices com os de outras entidades. Por meio dessas informações é possível que os gestores adiram a uma base mais estruturada para tomar as decisões adequadas para o futuro da empresa (GOMES; LAURINDO, 2014).

O estudo de Silva (2014) recomenda que ao término de cada exercício social, é dever da diretoria a elaboração, com base na escrituração mercantil da empresa, realizar algumas demonstrações financeiras. Essas devem exprimir, de forma clara e objetiva, a situação do patrimônio da organização bem como as mutações ocorridas neste período. Tais informações devem ser expressas por meio do balanço patrimonial; da demonstração dos lucros ou prejuízos acumulados; da demonstração do resultado do exercício e da demonstração dos fluxos de caixa. Caso se trate de uma companhia aberta, deve-se demonstrar o valor adicionado. Os dados obtidos com a Análise das Demonstrações Contábeis destinam-se a um grupo amplo de usuários (stakeholders) internos e externos que podem utilizar os dados para tomarem decisões de financiamento e investimento.

\section{ESTRUTURA DAS DEMONSTRAÇÕES CONTÁBEIS}

Para Pimentel e Almeida (2019) e Assaf Neto (2015), por meio da Análise das Demonstrações Contábeis executada por uma entidade, consegue-se extrair dados relacionados à posição econômica e financeira dessa empresa. Assim sendo, como tem-se discutido sobre as demonstrações, torna-se necessário observar os fatores determinantes da evolução e das perspectivas futuras de uma organização. Tais 
fatores permitem que, a partir dos resultados da análise, os gestores tomem decisões de forma mais coerente para com os objetivos e metas traçados pela própria empresa.

\section{BALANÇO PATRIMONIAL}

Para Assaf Neto (2015), o balanço representa os aspectos patrimoniais e financeiros de uma organização em um determinado período. Esse aspecto fornece informações totalmente estáticas, e, dessa forma, sua estrutura é, relativamente, diferente, após um tempo de seu encerramento. Todavia, devido à prestação de informações relevantes sobre as tendências que podem ser extraídas a partir de grupos de contas, o balanço serve como um elemento crucial e indispensável para que seja possível conhecer a situação financeira e econômica de uma organização. Em conformidade com a Lei 6.404/76, art. 178, ficou estabelecido que todas as contas devem ser classificadas de acordo com os seus elementos patrimoniais, as quais serão registradas e agrupadas de modo a viabilizar a análise e o conhecimento da situação financeira da companhia (FARIA, 2017; RODRIGUES, 2009).

Os elementos patrimoniais estão interligados com a mensuração da posição patrimonial e financeira, e, dessa forma, representam os ativos, os passivos e o patrimônio líquido. $O$ ativo deve ser entendido como um recurso que é controlado pela empresa. É resultado dos eventos passados e do que se espera, no futuro, em termos de benefícios econômicos para essa empresa. Já o passivo pode ser entendido como a obrigação da organização. Deriva de eventos passados, e, assim, espera-se que a liquidação resulte na saída de recursos para a geração de benefícios de caráter econômico. Por fim, o patrimônio líquido deve ser compreendido como o valor residual dos ativos da empresa depois de deduzidos os seus passivos de forma integral (CFC, 2008). 
Quadro 2: Modelo de Estrutura do Balanço Patrimonial

\begin{tabular}{|l|l|}
\hline \multicolumn{1}{|c|}{ Ativo } & \multicolumn{1}{c|}{ Passivo + Patrimônio Líquido } \\
\hline Ativo Circulante & Passivo Circulante \\
Ativo Não Circulante & Passivo Não Circulante \\
Realizável a Longo Prazo & Patrimônio Líquido \\
Investimento & Capital Social \\
Imobilizado & $(-)$ Gastos com Emissão de Ações \\
Intangivel & Reservas de Capital \\
& Opções Outorgadas Reconhecidas \\
& Reservas de Lucros \\
& $(-)$ Ações em Tesouraria \\
& Ajustes de Avaliação Patrimonial \\
& Ajustes Acumulados de Conversão \\
& Prejuízos Acumulados \\
\hline Obs: Ações em Tesouraria é conta retificadora da reserva utilizada para tal fim. \\
\hline
\end{tabular}

Fonte: Silva (2014)

É responsabilidade da empresa a apresentação de ativos circulantes e não circulantes (como grupos de contas separados no balanço patrimonial), exceto quando a apresentação baseada na liquidez proporcionar informações mais relevantes e confiáveis (CPC 26, 2011). Assim sendo, quando essa exceção for aplicável, todos os ativos e passivos precisam ser representados pela ordem de liquidez. A alteração da lei 6404/76 para a 11638/07 evocou mudanças inerentes à compreensão e extensão, como, por exemplo, nas avaliações dos critérios para avaliação do ativo; os critérios de avaliação do passivo; proibição da reavaliação espontânea de ativos; aplicação do teste de recuperabilidade de ativos (teste do impairment); registro em contas do ativo e passivo, dos contratos de arrendamento mercantil (leasing); a forma de escrituração.

Houve-se, também, as alterações nos aspectos relacionados ao tratamento fiscal e a eliminação da Demonstração das Origens e Aplicações de Recursos (DOAR), substituída pela Demonstração dos Fluxos de Caixa. Deve-se enfatizar que essa demonstração não é obrigatória para companhias fechadas que contam com um patrimônio líquido inferior a $R \$ 2.000 .000,00$. Também houveram alterações na 6404/76 com a lei 11.941/09, que trata da responsabilidade dos sócios e administradores quanto a encargos tributários, debêntures, versando, neste contexto, sobre o parcelamento especial, remissão de dívida e processo administrativo. 


\section{DEMONSTRAÇÃO DO RESULTADO DO EXERCícIO (DRE)}

A demonstração do resultado do exercício é deve ser entendida como um resumo que organiza ora as receitas ora as despesas de uma entidade em um momento determinado (este período pode equivaler a até doze meses) (ANASTÁCIO, 2004; SILVA, 2016; RODRIGUES, 2009). A sua apresentação é feita de forma dedutiva (ou vertical), e, dessa forma, subtrai-se, das receitas, as despesas, para, posteriormente, indicar-se o resultado, ou seja, o lucro ou o prejuízo, conforme ilustrado no quadro 3.

Quadro 3: Estrutura de Demonstrações de Resultado do Exercício

\begin{tabular}{|c|}
\hline Demonstração do Resultado do Exercício \\
\hline $\begin{array}{l}\text { RECEITA BRUTA DE VENDAS E SERVIÇOS } \\
\text { (-). Impostos, devoluções e descontos sobre vendas e serviços }\end{array}$ \\
\hline $\begin{array}{l}\text { RECEITA LIQUIDA DE VENDAS E SERVICCOS } \\
\text { (-) Custo das mercadorias vendidas e serviços prestados }\end{array}$ \\
\hline LUCRO BRUTO \\
\hline $\begin{array}{l}\text { RECEITAS DESPESAS OPERACIONAIS } \\
\text { (-) Com vendas } \\
\text { (-) Gerais e administrativas } \\
\text { (-) Honorários dos administradores } \\
\text { (-) Depreciação e amortização } \\
\text { (+i) Participação em controladas e controlada em conjunto } \\
\text { (+i-) Outras receitas despesas operacionais }\end{array}$ \\
\hline LUCRO OPERACIONAL ANTES DO RESULTADO FINANCEIRO \\
\hline RESULTADO FINANCEIRO \\
\hline $\begin{array}{l}(+) \text { Receitas financeiras } \\
(-) \text { Despesas Financeiras }\end{array}$ \\
\hline $\begin{array}{l}\text { Lucro do exercício antes dos impostos de renda, contribuição social e das participações } \\
\text { Imposto de renda e contribuição social } \\
\text { (-) Corrente } \\
\text { (-) Diferido }\end{array}$ \\
\hline $\begin{array}{l}\text { Lucro do exercício antes das participações } \\
\text { (-) Participação de acionistas não controladores }\end{array}$ \\
\hline $\begin{array}{l}\text { Lucro do exercício antes das participações minoritárias } \\
\text { (-) Participações minoritárias }\end{array}$ \\
\hline LUCRO LIQUIDO DO EXERCICIO \\
\hline Lucro líquido do exercício por ação do capital social em circulação no final do exercício \\
\hline Quantidade de ações do capital social em circulação no final do exercício \\
\hline
\end{tabular}

Fonte: Silva (2014) 
A demonstração de resultados do exercício tem como escopo principal fornecer, de forma estratégica, os resultados de lucro ou prejuízo auferidos por uma organização em um dado período de sua atuação. Esses, de maneira geral, são transferidos para contas do patrimônio líquido (ASSAF NETO, 2015; ANASTÁCIO, 2004; SILVA, 2016; RODRIGUES, 2009).

\section{DEMONSTRAÇÃO DOS LUCROS E PREJUÍZOS ACUMULADOS (DLPA)}

A DLPA viabiliza a relação entre o Balanço Patrimonial e a Demonstração de Resultados do Exercício (DRE). Seu objetivo básico é o de demonstrar a destinação do lucro líquido do exercício: parcela distribuída aos acionistas e aquela retida pela empresa para reinvestimento (ASSAF NETO, 2015). Segue o quadro 4.

Quadro 4: Estrutura da DLPA
SALDO INICIAL
(+/-) Ajustes de Exercícios Anteriores
(-) Parcela de Lucros Incorporada ao Capital Social
(+) Reversões de Reservas
(+/-) Resultado Líquido do Exercício
(-) PROPOSTA DE DESTINAÇÃO DO LUCRO

Transferências para Reservas

Dividendos a Distribuir

Juros Sobre o Capital Próprio

(=) SALDO FINAL 
Fonte: Assaf Neto (2015)

A Lei 6.404/76, em seu artigo 186, enfatiza que a demonstração dos lucros ou prejuízos acumulados deverá discriminar o saldo do início do período, os ajustes dos exercícios anteriores e a correção monetária do saldo inicial ajustado, de forma a atender as diretrizes legais. Recomenda-se, ainda, que as reversões de reservas bem como o lucro líquido do exercício devem ser executados para a efetivação da distribuição das receitas; para as transferências para as reservas; para os dividendos; para a parcela dos lucros incorporada ao capital e para o saldo ao fim do período (ANASTÁCIO, 2004; SILVA, 2016; RODRIGUES, 2009).

\section{DEMONSTRAÇÃO DOS FLUXOS DE CAIXA (DFLC)}

Assaf Neto (2015), em seu estudo, alude que a DFLC torna viável que se analisa a capacidade financeira de uma entidade e se esta honra para com os seus compromissos perante terceiros, sobretudo em relação às transações de empréstimos e financiamentos bem como perante aos acionistas (dividendos). Nesse sentido, a geração dos resultados futuros do caixa; as operações atuais; a posição da liquidez e a solvência financeira são elementos importantes de serem analisados (ANASTÁCIO, 2004; SILVA, 2016; RODRIGUES, 2009). A Lei 6.404/76 e a sua alteração na Lei 11.638/07, passou a compreender que fazem parte da DFLC as ações ocorridas durante o exercício no saldo de caixa assim como nos equivalentes de caixa. Essas alterações se manifestam em, pelo menos, três fluxos das operações, financiamentos e investimentos, conforme o quadro 5.

Quadro 5: Demonstração dos fluxos de caixa

\section{ATIVIDADES OPERACIONAIS}

- Lucro líquido do exercício

- Despesas (receitas) que não afetam o caixa e equivalentes

\section{Depreciações e amortizações}


Valor residual do imobilizado baixado

Resultado de equivalência patrimonial

\section{Outros}

- (Aumento) redução no Ativo Circulante Operacional

Contas a receber

\section{Estoques}

Outros

- Aumento (redução) no Passivo Circulante Operacional

Fornecedores

Impostos a pagar

Salários e encargos

Outros

Caixa Gerado (absorvido) pelas Atividades Operacionais

ATIVIDADES DE INVESTIMENTO

Títulos e valores mobiliários

Venda de Investimento/Imobilizado

Dividendos recebidos de controlada e coligada

Aquisição de bens do Imobilizado 
Caixa Gerado pelas (Utilizado nas) Atividades de Investimento

ATIVIDADES DE FINANCIAMENTO

Pagamento de dividendos e juros sobre o capital próprio

Captação de empréstimos e financiamentos

Amortização de Empréstimos e financiamentos - principal/juros

Caixa Gerado (utilizado) nas Atividades de Financiamento

GERAÇÃO (ABSORÇÃO) LÍQUIDA DE CAIXA

+ SALDO INICIAL DO CAIXA *

$=$ SALDO FINAL DO CAIXA*

Fonte: Matarazzo (2010)

Para Matarazzo (2010), a DFLC viabiliza a análise dos elementos de caráter financeiro da empresa, sobretudo os processos voltados às movimentações de investimento e de financiamento bem como se preocupa com a administração da empresa, e, assim, visa obter e aplicar, de forma compatível, os recursos.

\section{ANÁLISE DE ENVOLTÓRIO DE DADOS}

Pimentel e Almeida (2019), defendem, em seu estudo, que a análise por envoltório de dados (DEA) foi, inicialmente, elaborada por Charnes, Cooper e Rhode, no ano de 1978. Contudo, o seu aprimoramento foi feito por Banker, Charnes e Cooper, no ano de 1984. Tinha-se como escopo avaliar e medir o desempenho de empresas que tomavam decisões de forma frequente. Assim, para Onusic, Nova e Almeida (2007), é preciso que essas organizações sejam homogêneas para que se obtenha os mesmos resultados a partir do uso dos mesmos insumos, ou seja, dos resultados. Deve haver variação, apenas, em termos de quantidade ou intensidade. Nessa 
perspectiva, os produtos (também chamados de saídas) são os resultados coletados nas empresas tomadoras de decisão. Os insumos (inputs), por sua vez, são usados para se chegar a uma entrada, ou seja, aos produtos.

Os valores observados nos outputs são os lucros e nos inputs atém-se ao patrimônio líquido, ou seja, atém-se aos recursos investidos pelos sócios para a obtenção de lucro. Segundo Casa Nova (2010), é nesse contexto que surgem as primeiras discussões sobre o DEA. Objetivava-se, principalmente, o desenvolvimento de um modelo baseado na análise da insolvência, pois pretendia-se modernizar os modelos voltados à análise do desempenho empresarial. Assim sendo, o DEA, popularmente, passou a ser entendido como um instrumento voltado à programação linear, e, dessa forma, o seu objetivo é a medição do desempenho dessas organizações no processo de tomada de decisão. É acionado, principalmente, quando as múltiplas entradas e saídas dificultam a comparação (LOVELL et. al., 2004; VILELA, 2004).

Para Périco e Rebelatto (2008), essa técnica deve ser compreendida não como um processo paramétrico, visto que não se faz uso de um mecanismo de produção prédefinido. Assim, é o mesmo para todas as empresas que objetivam realizar uma análise do relacionamento no formato input-outout. Destarte, para que o seu uso seja possível, não é necessária a elaboração de uma fórmula ponderada fixa para que a eficiências das organizações possa ser medida, e, assim, avaliada. Nota-se, então, que os valores de cada uma das variáveis acabam sendo determinados pela própria técnica. Segundo Ceretta e Costa Junior (2001), tem-se como resultado da aplicação da análise por envoltório de dados, a classificação das unidades avaliadas, variando desde empresas até setores, investimentos e semelhantes, a partir de dois fatores: eficiente e ineficiente.

Já Peña (2008), alude que a boa combinação dos insumos e métodos inerentes (inputs) no processo produtivo, sobretudo quando se gera o máximo do produto (output), é o que determinará a eficiência dessa empresa. Esse fenômeno reitera que a eficiência deve ser entendida como a capacidade de fazer certo as coisas e a habilidade para se minimizar a relação dos insumos com os produtos. Assegura, ainda, a otimização no uso dos recursos, e, dessa forma, está interligada aos meios e 
não às finalidades. Existe, na literatura, dois modelos de DEA: o CCR e o BCC. Ambos se configuram a partir de duas formas para a maximização da eficiência: visam reduzir o consumo de insumos, mantendo, ao mesmo tempo, o mesmo nível de produção e pretendem aumentar a produção a partir dos dados inerentes aos níveis de insumos, e, dessa forma, orientam-se de acordo com o produto.

O estudo de Casa Nova (2002), elucida que diferença entre esses dois modelos é que o CCR tem como escopo principal o cálculo da eficiência total bem como dos retornos constantes em termos de escala para a identificação de fontes e estimativas de montantes frente às ineficiências identificadas e o BCC, segundo a pesquisa de Onusic, Nova e Almeida (2007), calcula a técnica que permite que organizações avaliadas apresentem retornos variáveis em sua escala. Analisa, então, se o acréscimo em uma unidade de insumo pode gerar acréscimos não proporcionais ao volume dos produtos. Entende-se, nesse contexto, que a eficiência de uma empresa apenas é alcançada quando o uso dos insumos é expressivo. Dessa forma, a eficiência é, sempre, relativa e apenas é válida dentro do seu contexto de atuação.

\section{ESTUDOS ANTERIORES}

Para melhor compreensão do tema exposto, torna-se necessária a explanação de algumas pesquisas publicadas que estão relacionadas ao tema central desta pesquisa. Para esta seção, foram buscados artigos técnico-científicos publicados em anais de eventos e em periódicos. No quadro a seguir, são apresentadas pesquisas similares com seus objetivos e principais resultados.

Quadro 6: Pesquisas anteriores similares a abordagem sobre informações contábeis e demonstrativos contábeis

Demonstrativos Contábeis

\begin{tabular}{|l|l|l|}
\hline Autores & Objeto de Estudo & $\begin{array}{l}\text { Temáticas abordadas e resultados } \\
\text { encontrados }\end{array}$ \\
\hline $\begin{array}{l}\text { Lisboa } \\
\mathbf{( 2 0 1 4 )}\end{array}$ & $\begin{array}{l}\text { Destacar a importância } \\
\text { da A pesquisa teve como objetivos analisar }\end{array}$ & $\begin{array}{l}\text { Análise } \text { das } \\
\text { as demonstrações contábeis para }\end{array}$ \\
\hline
\end{tabular}




\begin{tabular}{|c|c|c|}
\hline & $\begin{array}{l}\text { Demonstrações } \\
\text { Contábeis para as } \\
\text { decisões gerenciais. }\end{array}$ & $\begin{array}{l}\text { respaldar as decisões gerenciais e } \\
\text { evidenciar a situação econômica e } \\
\text { financeira das organizações, } \\
\text { descrevendo a forma que as empresas } \\
\text { efetuam a Análise das demonstrações } \\
\text { Contábeis. Os elementos obtidos nas } \\
\text { análises fazem com que as } \\
\text { demonstrações deixem de ser apenas um } \\
\text { conjunto de dados e passem a ter valor } \\
\text { como informação, permitindo ao usuário } \\
\text { a avaliação da situação da organização, } \\
\text { e assim utilizá-la como suporte para } \\
\text { decisões futuras, visando sempre o } \\
\text { objetivo da entidade e a minimização de } \\
\text { riscos. }\end{array}$ \\
\hline $\begin{array}{l}\text { Rodrigues } \\
\text { et al. (2015) }\end{array}$ & $\begin{array}{l}\text { Analisar o emprego dos } \\
\text { indicadores econômico- } \\
\text { financeiros aplicáveis nas } \\
\text { demonstrações } \\
\text { contábeis de uma } \\
\text { empresa. }\end{array}$ & $\begin{array}{l}\text { O presente estudo, objetivou } \\
\text { "contextualizar a Contabilidade como } \\
\text { instrumento para fornecer informações } \\
\text { aos seus usuários para à tomada de } \\
\text { decisão empresarial". Identificar os } \\
\text { indicadores econômico-financeiros e as } \\
\text { teorias de análise das Demonstrações } \\
\text { Contábeis no período de } 2011 \text { a } 2013 \text {. } \\
\text { Teve como conclusão, que através das } \\
\text { análises dos indicadores econômico- } \\
\text { financeiros se pode identificar a saúde } \\
\text { financeira da empresa e auxiliar na } \\
\text { tomada de decisão dos gestores. Nos } \\
\text { anos analisados a empresa apresentou } \\
\text { um resultado insatisfatório na liquidação } \\
\text { de suas obrigações, pois } 91 \% \text { do seu }\end{array}$ \\
\hline
\end{tabular}




\begin{tabular}{|c|c|c|}
\hline & & $\begin{array}{l}\text { ativo total correspondem ao imobilizado } \\
\text { que deveria produzir renda por trata-se } \\
\text { de uma locadora de veículos. "Pode-se } \\
\text { afirmar, ao final da pesquisa, que a } \\
\text { análise das demonstrações contábeis é } \\
\text { um instrumento eficiente para a tomada } \\
\text { de decisão". }\end{array}$ \\
\hline $\begin{array}{l}\text { Silva et al. } \\
(2016)\end{array}$ & $\begin{array}{l}\text { A contribuição da análise } \\
\text { das demonstrações } \\
\text { contábeis no processo de } \\
\text { concessão de crédito das } \\
\text { instituições financeiras. }\end{array}$ & $\begin{array}{l}\text { Os objetivos da pesquisa são identificar o } \\
\text { que a análise das demonstrações } \\
\text { contábeis fornece para a análise de } \\
\text { crédito e qual a importância dessas } \\
\text { informações; analisar se a fonte da } \\
\text { demonstração contábil contribui para sua } \\
\text { confiabilidade ou não. Concluiu-se que } \\
\text { que a análise das demonstrações } \\
\text { contábeis fornece uma boa visão da } \\
\text { estrutura financeira da empresa, através } \\
\text { dela possível verificar a evolução } \\
\text { patrimonial e seu grau de endividamento, } \\
\text { que serão fundamentais na decisão de } \\
\text { crédito; A Análise dos demonstrativos } \\
\text { contábeis representam } 70 \% \text { da decisão } \\
\text { do processo de crédito; a fonte da } \\
\text { informação contábil é de extrema } \\
\text { importância para uma análise mais } \\
\text { confiável; a análise das demonstrações } \\
\text { contábeis fornecem dados de extrema } \\
\text { importância para o processo de } \\
\text { concessão de crédito. }\end{array}$ \\
\hline
\end{tabular}




\section{Nota: Autores dispostos em ordem cronológica das publicações citadas; as publicações são: Periódicos - Artigos técnico-científicos publicados em periódicos (revistas, boletins, etc.).}

Fonte: Elaborado pelos autores com base nas fontes citadas, (2018)

Para Casa Nova (2010), as pesquisas buscaram identificar e analisar estudos que dispunham sobre a utilização das Informações e Demonstrativos Contábeis para a tomada de decisão, evidenciando, sobretudo, a importância das informações contábeis para resolução de problemas organizacionais. Tais informações permitem que a contabilidade seja uma fonte de informação para a aferição do desempenho econômico das empresas bem como favorece e permite que haja uma conjunção entre indicadores contábeis e métodos quantitativos específicos. Assim sendo, oferece ferramentas para gestores ou administradores efetuarem a avaliação de desempenho econômico de empresas (CASA NOVA, 2010).

Quadro 7: Pesquisas anteriores similares a abordagem sobre Análise por Envoltório de Dados e Diagnostico empresarial

Análise por Envoltório de Dados

\begin{tabular}{|c|c|c|}
\hline es & Estudo & $\begin{array}{l}\text { Temáticas abordadas } \\
\text { resultados encontrados }\end{array}$ \\
\hline $\begin{array}{l}\text { Ferreira e } \\
\text { Cister (2011) }\end{array}$ & $\begin{array}{l}\text { Estimular o uso da Análise por } \\
\text { Envoltório de Dados (DEA) como } \\
\text { uma ferramenta efetiva na } \\
\text { avaliação da performance de } \\
\text { fundos de investimento. }\end{array}$ & $\begin{array}{l}\text { O DEA é um método } \\
\text { determinístico que não pode } \\
\text { ser usado de forma universal } \\
\text { para avaliar a performance de } \\
\text { fundos. }\end{array}$ \\
\hline $\begin{array}{l}\text { Casa Nova } \\
(2010)\end{array}$ & $\begin{array}{l}\text { Construir, testar e comparar } \\
\text { modelos de análise de } \\
\text { inadimplência/insolvência aliando } \\
\text { análise de balanços e Análise por } \\
\text { Envoltória de Dados (DEA). }\end{array}$ & $\begin{array}{l}\text { Os resultados dos modelos } \\
\text { DEA não foram comparáveis } \\
\text { aos obtidos dos modelos de } \\
\text { Regressão Logística e Redes } \\
\text { Neurais para a amostra da }\end{array}$ \\
\hline
\end{tabular}




\begin{tabular}{|c|c|c|}
\hline & & $\begin{array}{l}\text { Melhores e Maiores, que inclui } \\
\text { empresas de diversos setores }\end{array}$ \\
\hline $\begin{array}{l}\text { Mariano, } \\
\text { Almeida, } \\
\text { Rebelatto } \\
(2006)\end{array}$ & $\begin{array}{l}\text { Sistematizar, de maneira objetiva, } \\
\text { os principais conceitos e } \\
\text { devoluções pertinentes ao cálculo } \\
\text { de eficiência, em especial á técnica } \\
\text { Análise por Envoltória de Dados } \\
\text { (DEA), apresentando-os em } \\
\text { linguagem clara e didática. }\end{array}$ & $\begin{array}{l}\text { Apresentação dos principais } \\
\text { modelos do DEA, CCR e BCC, } \\
\text { com todas as suas variações, } \\
\text { primal e dual orientados ao } \\
\text { input e ao output, permitiu a } \\
\text { construção de um painel do } \\
\text { que de há de mais citado na } \\
\text { literatura a respeito do cálculo } \\
\text { de eficiência relativa por meio } \\
\text { dessa técnica. }\end{array}$ \\
\hline $\begin{array}{l}\text { Gomes, } \\
\text { Mangabeira } \\
\text { e Mello } \\
(2005)\end{array}$ & $\begin{array}{l}\text { Medir eficiência de produtores } \\
\text { agrícolas permite indicar quem é } \\
\text { eficiente, as razões para a } \\
\text { ineficiência e os produtores cujas } \\
\text { práticas podem servir de referência } \\
\text { para os ineficientes }\end{array}$ & $\begin{array}{l}\text { Modelos DEA avançados } \\
\text { podem melhorar os resultados } \\
\text { obtidos, seja na redução dos } \\
\text { pesos zero, seja na } \\
\text { possibilidade de seleção de } \\
\text { alvos a alcançar. Outro } \\
\text { aspecto importante é o uso de } \\
\text { variáveis não incluídas no } \\
\text { modelo e que possam explicar } \\
\text { as ineficiências e gerarem } \\
\text { informações, para as } \\
\text { instituições de pesquisa, } \\
\text { desenvolvimento e extensão } \\
\text { rural, no intuito de melhorar a } \\
\text { eficiência dos produtores } \\
\text { ineficientes }\end{array}$ \\
\hline $\begin{array}{l}\text { Santos e } \\
\text { Casa Nova } \\
(2005)\end{array}$ & $\begin{array}{l}\text { Apresentar um modelo estruturado } \\
\text { de análises de demonstrações }\end{array}$ & $\begin{array}{l}\text { A pesquisa demonstrou que } \\
\text { modelo proposta é completar }\end{array}$ \\
\hline
\end{tabular}


contábeis, baseado em análise por aos métodos de avaliação de envoltório de dados. empresas.

Nota: Autores dispostos em ordem cronológica das publicações citadas; as publicações são: Periódicos - Artigos técnico-científicos publicados em periódicos (revistas, boletins, etc.).

Fonte: Elaborado pelos autores com base nas fontes citadas, (2018).

Conforme Silva et al (2016), esses trabalhos tiveram como intuito a verificação e análise sobre como tem-se utilizado as Informações e Demonstrativos Contábeis nos processos de tomada de decisão. Essas pesquisas direcionam o olhar dos interessados para que esses entendam a importância das informações contábeis para a resolução dos problemas de origem organizacional. Entendem, ainda, que o envoltório de dados e análises devem ser aplicados para que se gere informações úteis. É um instrumento de gestão bastante efetivo para o processo decisório organizacional, visto que legitima uma vantagem competitiva no cenário empresarial moderno. Neste sentido, Reis (2017) sinaliza que um dos problemas de mais difícil solução na análise dos demonstrativos contábeis é o da correta interpretação dos resultados numéricos obtidos.

Nesse contexto, fenômenos como a separação de dados e sua combinação de forma coerente a fim de viabilizar sua interpretação são importantes. Neste sentido, Lacerda et al. (2013), apontam que aqueles que souberem aplicar as informações contábeis de forma eficaz podem alcançar posição de destaque diante dos concorrentes. Em continuidade, torna-se necessário ressaltar a importância das análises dos demonstrativos contábeis, pois através destas, se torna possível organizar o orçamento e controlar os gastos das organizações. Portando, é uma das principais ferramentas para auxiliar a tomada de decisão (LISBOA, 2014). Tais pesquisas, assim como o presente estudo, entendem que os demonstrativos contábeis são considerados como ferramentas de grande importância na tomada de decisão nas organizações, proporcionando um melhor diagnóstico empresarial sobre a situação financeira da empresa em determinado tempo, promovendo vantagens competitivas em comparação com os concorrentes. 


\section{METODOLOGIA}

Para o desenvolvimento deste estudo optou-se por uma pesquisa descritiva. Este tipo de pesquisa torna possível uma maior aproximação para com a realidade descrita, e, dessa forma, viabiliza a amplia a percepção sobre os elementos essenciais para a compreensão detalhada (GIL, 1995; LAKATOS, MARCONI, 2000). Torna-se possível, ainda, compreender e detalhar o fluxo de informações na perspectiva de entrada, processo e saída de informações (OLIVEIRA; 2001; PADOVEZE, 2009, DIAS, VASCONCELOS, 2011). A pesquisa qualitativa, matéria deste estudo, difere-se das pesquisas quantitativas pois valoriza a visão e a perspectiva dos agentes envolvidos de forma mais ampla. Isso faz com que o pesquisador seja capaz de se apropriar de um vasto repertório de métodos e técnicas para a exploração da realidade (VASCONCELOS et al, 2017).

Segundo Silva (2003), a partir da coleta de dados, escolheu-se trabalhar com duas etapas para a concretização da análise. Essa estratégia se encontra fundamentada no método de estudo por etapas. Este enfatiza que a investigação deve ser feita de maneira ordenada e o escopo principal é o de atingir uma determinada finalidade, e, com isso, fazer o uso, de forma mais hábil, segura e eficiente da técnica. Assim sendo, em um primeiro momento, optou-se pela busca por demonstrativos contábeis da empresa na JUCEPA. Teve-se como intuito realizar uma análise de caráter financeiro e econômico sobre a empresa "Y". Com esses dados, será possível apresentar ações voltadas ao diagnóstico da organização a partir de uma pesquisa ação a ser realizada em lócus na organização. Esse processo será finalizado na segunda etapa da pesquisa.

A empresa estudada foi denominada "empresa $Y$ ". Sua sede se localiza em Capanema-PA, situada na Avenida Barão de Capanema, Centro. A empresa atua no ramo de atividade econômica de comércio varejista e é especializada em eletrodomésticos, móveis, artigos do vestuário e acessórios e equipamentos de áudio e vídeo. A empresa atua no comércio a 57 anos e conta com doze filiais em sete munícipios vizinhos: Salinas, São João de Pirabas, Primavera, São Miguel do Guamá, Igarapé-Açu, Castanhal, Santa luzia do Pará, Santa Maria do Pará, Irituia, Piriá, Mãe 
do Rio. A filial mais recente é a de Nova Esperança. Possui uma grande estrutura para atender a demanda da região, e, assim, conta com mais de 200 colaboradores diretos e dezenas de parceiros comerciais.

Optou-se, nesse estudo, pelo DEA, por não haver estudos voltados para a eficiência de uma única empresa, e, assim, seus principais estudos são voltados para estudo de insolvência e solvência comparativa de diversas empresas (CASANOVA, 2010), modelos de análise de demonstrações contábeis (SANTOS, CASANOVA, 2005), estudos aplicados à caracterização da agricultura (GOMES, MANGABEIRA, MELLO), dentre outros. Nota-se que todos tem como escopo principal fazer uso do DEA para medir a eficiência organizacional. O modelo de DEA escolhido para esta pesquisa foi BCC. Ele se revelou como necessário pois calcula a eficiência técnica, e, dessa forma, classificou para a análise os produtos e os insumos para pesquisa. Segue quadro abaixo.

Quadro 8: Classificação de indicadores

\begin{tabular}{|l|l|l|l|}
\hline Indicador & Base & Abrev. & Variável \\
\cline { 3 - 4 } & & & DEA \\
\hline \multirow{3}{*}{ Liquidez } & Liquidez Corrente & LC & Produto \\
\cline { 2 - 4 } & Liquidez Geral & LG & Produto \\
\cline { 2 - 4 } & Liquidez Seca & LS & Produto \\
\hline \multirow{2}{*}{ Endividamento } & Endividamento Geral (em \%) & IEG & Insumo \\
\cline { 2 - 4 } & Capital de terceiros & IPCT & Insumo \\
\cline { 2 - 4 } & Composição de endividamento & ICE & Insumo \\
\cline { 2 - 5 } & Imobilização do PL & IPL & Insumo \\
\hline \multirow{2}{*}{ Rentabilidade } & Lucro em um determinado período & & Insumo \\
\cline { 2 - 4 } & & & \\
\hline
\end{tabular}

Fonte: Elaborado pelos autores, (2018)

Ao optar-se pelo DEA, a pesquisa se propôs a trabalhar com o método qualitativo para a avaliação. Dessa forma, contou-se com as recomendações da revisão da literatura para a aplicação de índices na análise. Posteriormente, confrontou-se os dados 
obtidos por meio da aplicação dos índices a partir de um modelo estatístico simples. Para tanto, utilizou-se os programas Excel $\AA$, da Microsoft $\AA$ e o SPSS 12.0, para Windows ${ }^{\circledR}$. Segundo Casa Nova (2002), com a base de análise estatística (que considera a média, o desvio padrão, os máximos e os mínimos) entre grupos de estudo, para que elas possam ser consideradas quando os seus resultados $(R)$ de eficiência média forem igual $a: R>0$, há eficiência e quando detectar-se: $R<0$ há ineficiência. Para a concretização dessa análise, a empresa " $Y$ " precisou de um certo grau de envolvimento humano e subjetivo para uma escala crescente de estruturação.

Conforme os estudos de Mariano, Almeida e Rebelatto (2006), a etapa da estruturação é fundamental e crucial para a determinação das etapas das análises posteriores. Assim sendo, precisam ser colocadas em uma sequência lógica. Nesse sentido, esse pesquisador-analista deve ser conduzido às conclusões para que possa apontar se há a necessidade de dados adicionais. Para a complementação do perfil de análise, acionou-se a base do diagnóstico de PMS, utilizado na segunda parte da pesquisa. Outro a ponto a ser discutido é que a principal limitação identificada na aplicação da DEA é o fato de ser técnica ser recente, quase restrita às áreas de pesquisa operacional e engenharia, e necessitando de ambientação para utilização em outras áreas do conhecimento.

Após a obtenção e observação dos dados da primeira e segunda fase, respectivamente, utilizou-se o programa Excel para a tabulação das informações. Destacou-se a relevância da informação dos demonstrativos contábeis para análise por resultados organizacionais e de sua importância no processo decisório. Após estas avaliações, consequentemente, foi realizada uma análise inerente às demonstrações contábeis como forma de demonstrar os ganhos que a organização possui ao efetuar uma avaliação composta em resultados e diagnósticos organizacionais que auxilia na tomada de decisão bem como no planejamento.

\section{ANÁLISE DE DADOS}

Segundo Pimentel e Almeida (2019), a análise de dados tem como referência as contribuições teóricas e metodológicas dos autores para produzir informações e 
métodos para conciliar a teoria contábil com a sua aplicabilidade, relatando, assim, a importância de cada item para a tomada de decisão do administrador.

\section{ANÁLISE DAS DEMONSTRAÇÕES CONTÁBEIS}

Para análise dos dados atribui-se a eficiência técnica das empresas através da análise das amostras de pesquisa, atribuída com a apresentação do resumo do demonstrativo contábil. ( $\mathrm{O}$ demonstrativo completo encontra-se no apêndice A) da empresa Y. Para o DEA as análises de demonstrações contábeis surgem para organizar e condensar a informação, permitindo afastar a subjetividade do analista, o que deve ser compreendido através de modelos de desempenho como fator multidimensional, ou fator de eficiência técnica e que somente será possível sua compreensão ou discutila mediante análise conjunta de indicadores (SANTOS; CASANOVA, 2005).

\section{ANÁLISE FINANCEIRA}

\section{ANÁLISE VERTICAL}

A análise vertical determina o percentual de cada conta ou grupo de contas em relação ao total de que faz parte, possibilitando saber qual o ativo a empresa está investindo mais, ou comparar se seu custo é mais elevado do que a concorrência (PASSOS, 2010). 
Tabela 1: Análise vertical do Balanço Patrimonial

\begin{tabular}{|c|c|c|c|}
\hline \multicolumn{3}{|c|}{ ATIVo } & \multirow{2}{*}{$\begin{array}{l}\text { AV } \% \\
100 \% \\
\end{array}$} \\
\hline ATIVo & \multicolumn{2}{|c|}{ TOTAL: R\$ $31.077 .217,41$} & \\
\hline Ativo Circulante & & R\$ $26.645 .368,19$ & $85,7 \%$ \\
\hline \multicolumn{2}{|l|}{ Caixa } & $33.631,99$ & $0,11 \%$ \\
\hline \multicolumn{2}{|l|}{ Bancos - Conta Movimento } & R\$ $\quad 1.110 .122,37$ & $3,6 \%$ \\
\hline \multicolumn{2}{|l|}{ Aplicações Inst. Financ. Nacionais } & R\$ $\quad 3.626 .604,82$ & $11,7 \%$ \\
\hline \multicolumn{2}{|l|}{ Contas a Receber } & R\$ $\quad 1.540 .951,84$ & $5,0 \%$ \\
\hline \multicolumn{2}{|l|}{ Outros Valores a Receber } & $677.068,28$ & $2,2 \%$ \\
\hline \multicolumn{2}{|l|}{ Estoque } & R\$ $19.656 .988,89$ & $63,2 \%$ \\
\hline \multicolumn{2}{|l|}{ Não circulante } & R\$ $\quad 4.431 .849,22$ & $14,3 \%$ \\
\hline \multicolumn{3}{|c|}{ PASSIVO } & AV $\%$ \\
\hline PASSIVO & \multicolumn{2}{|c|}{ TOTAL: $\quad$ R $\$ 31.077 .217,41$} & $100 \%$ \\
\hline \multicolumn{2}{|l|}{ Passivo Circulante } & $\mathrm{R} \$ 16.451 .121,32$ & $\mathbf{5 2 , 9 \%}$ \\
\hline \multicolumn{2}{|l|}{ Contas a Pagar } & R\$ $14.529 .779,12$ & $46,72 \%$ \\
\hline \multicolumn{2}{|l|}{ Folha de Pagamento } & $313.964,50$ & $1,0 \%$ \\
\hline \multicolumn{2}{|l|}{ Obrigações Tributárias } & R\$ $\quad 1.056 .517,25$ & $\mathbf{3 , 4} \%$ \\
\hline \multicolumn{2}{|l|}{ Não Circulante } & R\$ $\quad 6.589 .017,36$ & $21,2 \%$ \\
\hline \multicolumn{2}{|l|}{ Patrimônio Líquido } & $\begin{array}{ll}\text { R } & 8.037 .078,73 \\
\end{array}$ & $\mathbf{2 5 , 9} \%$ \\
\hline \multicolumn{2}{|l|}{ Capital integralizado } & R\$ $\quad 3.200 .000,00$ & $10,3 \%$ \\
\hline Reservas e Lucros acumulados & & R\$ $4.837 .078,73$ & $15,6 \%$ \\
\hline
\end{tabular}

Fonte: JUCEPA (2018)

De acordo com a tabela acima, vale destacar o Ativo Circulante que compõe 85,7\% do Ativo Total. Nesse contexto, é algo benéfico perante a visão do administrador, pois em caso de dívidas o saldo do ativo circulante pode ser utilizado para honrar estes pagamentos após uma determinação da justiça. Porém, vale alarmar sobre os $63,2 \%$ da representação do Estoque no Circulante. Este se trata do dinheiro preso, que, para Matarazzo (2010), não pode ser empregado em outras ações. Assim sendo, o Ativo Circulante é composto por $85,7 \%$ e o Não Circulante totaliza $14,3 \%$ do Ativo Total. Isso revela que a empresa deve cumprir os acordos financeiros e saldar as dívidas. Posteriormente, registrou-se que o Ativo Circulante é maior que o Passivo Circulante. 
Conclui-se, então, que o capital de giro líquido da empresa é positivo quando consegue saldar suas obrigações a curto prazo.

Partindo desta premissa, esta análise possibilita uma melhor visualização acerca do percentual de cada conta em relação ao total do qual faz parte, ou seja, permite verificar se a empresa consegue arcar com suas obrigações de curto e longo prazo, ociosidade dos estoques e ter maior controle gerencial de cada conta perante as necessidades e planejamento da organização (SILVA, 2016; ANASTÁSIO, 2004; CAMELO et al, 2007; HANAOKA; LEON, 2013). Ratifica-se, assim, as premissas de diversos autores como Medeiros (2012), Lima e Lima (2013) e Rodrigues (2015). Eles avaliam a analise vertical como índice importante na identificação a da aplicação dos recursos de uma organização sendo o primeiro passo holístico, capaz de atentar sobre aos a serem praticadas em prol da melhoria financeira da empresa.

\section{ANÁLISE ECONÔMICA}

$\mathrm{Na}$ capacidade de endividamento é feita através de índices, onde enfatizam o nível de dependência de capital de terceiros financiando o Ativo e em que proporção isso ocorre (MATARAZZO, 2010, MEDEIROS, 2012). A partir dos dados do Balanço patrimonial obtivemos os resultados dos quatro principais índices a serem calculados, onde tais vem mostrar a capacidade de endividamento da empresa e de qual recurso a empresa utiliza mais, se capital de terceiros ou próprio (PIMENTEL; ALMEIDA, 2019). 
Tabela 2: Análise econômica da empresa $Y$

\begin{tabular}{|c|c|}
\hline \multicolumn{2}{|c|}{ Capacidade de endividamento } \\
\hline ÍNDICE & $\%$ \\
\hline IPCT-Índice de Participação do Capital de Terceiros & $287 \%$ \\
\hline ICE- Índice de Composição do Endividamento & $71,4 \%$ \\
\hline IGE- Índice de Endividamento Geral & $74 \%$ \\
\hline IPL- Imobilização do Patrimônio Líquido & $77 \%$ \\
\hline \multicolumn{2}{|c|}{ Liquidez } \\
\hline ÍNDICE & $\%$ \\
\hline Liquidez Geral & $135 \%$ \\
\hline Liquidez Corrente & $162 \%$ \\
\hline Liquidez Seca & $42 \%$ \\
\hline
\end{tabular}

Fonte: Elaborado pelos autores (2018)

Diante do exposto, é evidente a importância destes indicies para empresas que pretendam manter, aperfeiçoar ou ampliar suas operações, pois é através dos Indicadores de Endividamento que as empresas avaliam o montante de suas dívidas obtidas através de Recursos de terceiros em função de seu Capital Próprio. Os dados apontam que os índices de endividamento informam a relação das origens de recursos entre si, e, dessa forma, revela o grau de dependência que a empresa possui em relação ao capital de terceiros (PIMENTEL; ALMEIDA, 2019). Analisando o Índice de Liquidez Seca, notou-se que a empresa possuía para cada $R \$ 1,00$ de dívidas existentes no passivo circulante, somente $\mathrm{R} \$ 0,42$ no ativo circulante. É necessário explanar sobre a desconsideração do estoque, pois são elementos de incerteza quanto a Liquidez, o mesmo pode ser vendido ou não, podendo ser demorado a sua transformação em dinheiro, condizentes com as abordagens de Alves (2011) e Gomes e Laurindo (2014).

\section{AVALIAÇÕES DA ANÁLISE DE ENVOLTÓRIO DE DADOS (DEA)}

Atualmente, um dos grandes debates no meio empresarial vem de alcançar a máxima eficiência nos seus processos produtivos. Fato esse, é vital para a sobrevivência no 
mercado globalizado (MARIANO; ALMEIDA; RABELATTO, 2006; PIMENTA; ALMEIDA, 2019). Para Casa Nova (2002) argumenta que a análise por envoltória de dados como sendo uma curva de eficiência, caracterizada nível máximo de produtividade, considerando a relação ótima entre insumos e produtos. Essa curva pode ser definida como uma fronteira de eficiência.

Dessa forma, as organizações consideradas eficientes estarão nessa curva enquanto as ineficientes se localizarão abaixo dela. $O$ que de fato unidades tomadoras de decisão (ou Decision Making Unit - DMU) a decidirem a melhor abordagem ou correções a serem feitas na organização, proporcionando que uma empresa ineficiente se torne uma empresa eficiente (MARIANO; ALMEIDA; RABELATTO, 2006; PIMENTA; ALMEIDA, 2019). Portanto, a técnica DEA é uma das principais ferramentas, apontadas pela literatura, para ajudar na resolução desse problema na questão de eficiência produtiva, o qual neste trabalho foi avaliado a eficiência técnica modelo conhecido como BCC.

Gráfico 1: Avaliação DEA

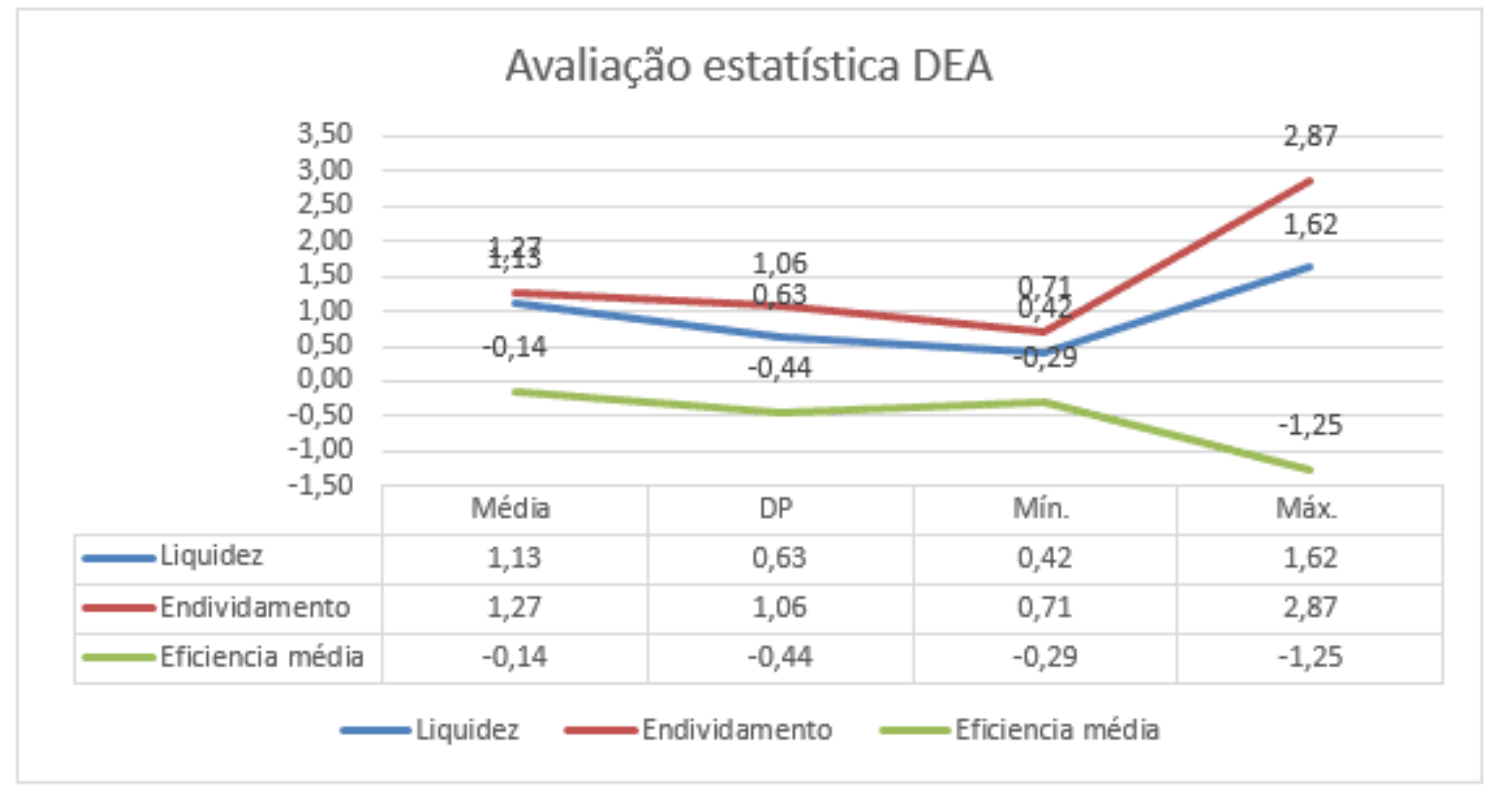

Fonte: Elaborado pelos autores (2018). 
Ao confrontar as informações de liquidez e endividamento, percebe-se que por mais que a empresa apresente estoques elevados compatíveis com os fornecedores (PIMENTA; ALMEIDA, 2019). Pela análise geral, observou-se que a empresa apresentou uma ineficiente, não consegue ter a garantia de cumprimento de suas obrigações com os credores, se não houve uma redução significativa do estoque. $O$ resultado obtido foi coerente, pois a premissa básica do modelo BCC é que os produtos e os insumos não sejam proporcionais, para que seja possível identificar o nível de eficiência ou ineficiência (MARIANO, ALMEIDA, REBELATTO, 2006; PIMENTA; ALMEIDA, 2019).

Notou-se neste processo de análise o devido padrão no item de eficiência media mostrou que o desvio padrão da amostra foi de $-0,44$, que significa que a empresa aplicar caminhos imediatos de reverter a situação, que ao avaliar os demonstrativos contábeis nos itens dos passivos, os maiores valores estão propostos nos fornecedores e financiamentos. Avaliou-se também que se confirma os argumentos de Casa Nova (2010), ao informar que o DEA é útil para discriminar empresas eficientes, tendo uma aplicação restrita como se teve na empresa estudada, para identificar sua atual situação ineficiente nos padrões técnicos.

\section{CONCLUSÃO}

Este estudo foi desenvolvido com o intuito de aplicar a Análise de envoltório de dados (DEA) a partir das análises dos Demonstrativos Contábeis como ferramenta de tomada de decisão na Empresa "Y". Os maiores desafios estiveram voltados à organização dos dados sobre as informações provenientes da interpretação dos demonstrativos contábeis. Outra dificuldade foi a avaliação dos termos que são manifestados dentro da questão em que se busca conhecer ou descobrir, nesse contexto, as aplicações do DEA. Por outro lado, as informações permitem identificar até o momento que as informações se tornam incompletas na organização por não ter dados necessários, as informações não são coerentes ao caso.

Perfazendo identificar a importância da padronização atividades e normatização técnicas de serviços possibilitam reduzir a variabilidade dos processos de trabalho 
sem prejudicar sua flexibilidade, identificada no momento das avaliações in loco, e também na consequente confecção dos demonstrativos contábeis. Tendo em vista que a causa desse tipo de informação encontra-se, na maioria das vezes, dentro do contexto em que as empresas não registram seus fatos e atos contábeis de maneira assimétrica, com a justificativa de que tais eventos se relacionam estritamente com as tomadas de decisões corriqueiras dentro de uma organização.

Assim, conclui-se que, por mais que se tenha um avanço de tecnologia, o capital humano não consegue alcançar todas estas mudanças, muitas vezes devido não ter as informações no prazo ou por não ter conhecimento de acordo do tipo jurídico da empresa ou atividade econômica. Conclui-se também que estudar a DEA como forma de tomada de decisão é importante para saber se a organização está se mantendo ineficiente ou eficiente. Entretanto, note que esta ferramenta bem aplicada deve ser ter conhecimento estatístico para conseguir medir os níveis de eficiência, assim como pensar em novas perspectivas de mudar a realidade organizacional uma para ter a eficiência. No caso estudado mostrou ineficiência, que pode ser dirimida com a redução do estoque, porém somente, o estoque não soluciona a questão.

O emprego do modelo DEA nesta avaliação mostrou-se de bastante interesse, em especial no que se refere à possibilidade de determinar diretrizes a serem melhoradas as quais foram diagnosticadas, para que se consiga mudar o quadro de ineficiente para o a eficiência (redução dos recursos estruturais e visuais e/ou aumento das vendas). Com as informações obtidas da amostra atual foi possível confirmar ou provar que é possível aplicar o DEA para avaliar a ineficiência e eficiência das empresas através da análise das demonstrações contábeis, e que estas informações são uteis para se conseguir diagnosticar a organizações e para se toma a decisão correta. Os resultados dos modelos DEA não foram comparáveis aos obtidos dos modelos de Regressão Logística devido precisar de um campo de amostra de exercícios maiores, que podem ser objeto de estudos posteriores. 


\section{REFERÊNCIAS}

ALVES, S. G; SILVA, I. A. da. Análise das demonstrações contábeis como ferramenta gerencial para auxílio no processo de tomada de decisão. In: SEMINÁRIO DE INICIAÇÃO CIENTíFICA CURSO DE CIÊNCIAS CONTÁBEIS DA FSG, 1., 2011, Serra Gaúcha. Anais II. Serra Gaúcha: FSG, 2011. p. 1-5, 2011.

ANASTÁCIO, A. C. Análise das demonstrações contábeis e sua importância na verificação da situação econômico-financeira das empresas. Monografia em Ciências Contábeis - Universidade Federal de Santa Catarina, Florianópolis, 2004.

ARAÚJO, J. C. O; CRUZ, L. D. C. Informação imperfeita ou incompleta: um estudo sobre a informação contábil nos escritórios de contabilidade de Capanema Pará. In: XV Congresso USP de Iniciação Científica, 2018.

ASSAF NETO, A. ESTRUTURA E ANÁLISE DE BALANÇOS: UM ENFOQUE ECONÔMICO-FINANCEIRO. 11. ed. São Paulo: Atlas, 2015.

AZZOLIN, J. L. Análise das demonstrações contábeis. IESDE BRASIL SA, 2012.

Banker, R. D., Charnes, A., Cooper, W. W. Some models for estimating technical and scale inefficiencies in data envelopment analysis. Management Science, v. 30, n. 9, p. 1078-1092, 1984.

BRASIL. Lei ํㅜ 6404, de 15 de dezembro de 1976. Dispõe Sobre As Sociedades Por Ações. Disponível em: http://www.planalto.gov.br/CCivil_03/Leis/L6404compilada.htm. Acesso em: 06 ago. 2018.

CAMELO, E. P. de. S. M. et al. Análise das demonstrações contábeis em empresas da área comercial de embalagens. FCV Empresarial, v. 1, p. 167-193, 2007. 
CARNAÚBA, W. M. ESTRUTURA DE CAPITAL: TEORIA DA AGENCIA, TEORIA DA SINALIZAÇÃO E TEORIA DO CONTROLE. Dissertação de Mestrado em Administração - Fundação Getúlio Vargas, São Paulo, 1993.

CASA NOVA, S.P.C. Utilização da análise por envoltória de dados (DEA) na análise de demonstrações contábeis. Tese (Doutorado em Ciências Contábeis) Universidade de São Paulo, São Paulo, 2002.

CASA NOVA, S. P. C. Bons em ser Ruins: A utilização da Análise por Envoltória de Dados (DEA) em modelos de análise de inadimplência/insolvência de empresas. In: XXXIV ENANPAD, 2010.

CERETTA, P. S; COSTA JUNIOR, N. C. A. da. Avaliação e seleção de fundos de investimento: um enfoque sobre múltiplos atributos. Revista de Administração Contemporânea, [s.I.], v. 5, n. 1, p.7-22, 2001.

Charnes, A., Cooper, W. W; Rhodes, E. Measuring efficiency of decision-making units. European Journal of Operational Research, v. 2, n. 4, p. 429-444, 1978.

COMITÊ DE PRONUNCIAMENTOS CONTÁBEIS. CPC 26: Apresentação das Demonstrações Contábeis. Brasília, 2011. 41 p. Disponível em: http://static.cpc.aatb.com.br/Documentos/312_CPC_26_R1_rev\%2012.pdf. Acesso em: 01 ago. 2018.

CONSELHO FEDERAL DE CONTABILIDADE. Resolução no 1.121, de 2008. Disponível em: http://www1.cfc.org.br/sisweb/SRE/docs/Res_1121.pdf> Acesso em: 05 ago. 2018.

CORREIA, J. J. A. et al. Análise das demonstrações contábeis como ferramenta de gestão: um estudo de caso numa microempresa do estado de Pernambuco. Revista de Empreendedorismo e Gestão de Micro e Pequenas Empresas, v. 1, n. 4, p. 125-142, 2016. 
DALMOLIN, V. et al. Análise vertical e horizontal: um estudo realizado nos demonstrativos financeiros de uma cooperativa do setor agroindustrial - RS. In: XXIII ENANGRAD, 2012.

DA SILVA, K. R; DE SOUZA, P. C. Análise das demonstrações financeiras como instrumento para tomada de decisões. INGEPRO-Inovação, Gestão e Produção, v. 3, n. 1, p. 67-78, 2011.

DA SILVA, M. P; COUTO, C. H. da. S; CARDOSO, A. A. B. Análise das Demonstrações Contábeis como Ferramenta de Suporte à Gestão Financeira. Revista Brasileira de Gestão e Engenharia - RBGE, n. 13, p. 23-45, 2016.

DE CARVALHO, V. G; SILVA, J. J; SILVA, C. A. T. Divulgação da Informação Contábil: Influência nas decisões de investimentos em ações. Registro Contábil, v. 4, n. 2, p. 36-54, 2013.

DE LACERDA MOREIRA, R. et al. A importância da informação contábil no processo de tomada de decisão nas micro e pequenas empresas. Revista Contemporânea de Contabilidade, v. 10, n. 19, p. 119-140, 2013.

FARIA, R. P. S. Análise de demonstrações contábeis: uma aplicação do balanço perguntado. Monografia em Administração - Instituto Federal de Educação, Ciência e Tecnologia, Ouro Branco, 2017.

FREITAS, M. B. et al. Informações contábeis e financeiras em microempresas: a visão de gestores da indústria de confecção em Sant'Ana do Livramento. 2017.

GOMES, G. A; LAURINDO, M. A. ANÁLISE DAS DEMONSTRAÇÕES CONTÁBEIS COMO FERRAMENTA DE GESTÃO: UM ESTUDO NA EMPRESA $X$. TCC (Graduação) - Curso de Bacharel em Ciências Contábeis 0 Instituto de Ensino Superior Blauro Cardoso de Mattos, Serra, 2014. 
GOMES, E. G; MANGABEIRA, J. A. de. C; MELLO, J. C. C. B. S. de. M. Análise de envoltória de dados para avaliação de eficiência e caracterização de tipologias em agricultura: um estudo de caso. RER, v. 43, n. 4, p. 607-631, 2005.

HANAOKA, C. H. T; LEON, F. H. A. D. Análise de Demonstrações Contábeis na Gestão Financeira de uma Entidade Sem Fins Lucrativos. Revista Ampla de Gestão Empresarial, São Paulo, v. 2, n. 2, p.1-21, 2013.

IUDÍCIBUS, Sérgio de. Análise de Balanços. 10. ed. São Paulo: Atlas 2014.

LIMA, A. F. A. de; LIMA, J. E. de. C. índices econômico-financeiros como instrumento para análise das demonstrações financeiras na tomada de decisão gerencial. Revista Interfaces: Saúde, Humanas e Tecnologia, v. 1, n. 3, p.1-16, 2013.

LISBOA, J. C. V. A importância da análise das demonstrações contábeis para suporte as decisões gerenciais das organizações. Administração de Empresas em Revista, v. 13, n. 14, p. 159-170, 2014.

LOVELL, C. A. K. Productions frontiers and productive efficiency. In: FRIED, SOARES MELLO J.C.C.B; GOMES E.G.; BIOND NETO L.; LINS M.P.E. Suavização da fronteira DEA: o caso BCC tridimensional. In: ASSOCIAÇÃO PORTUGUESA DE DENTEINVESTIGAÇÃO OPERACIONAL, 2004.

MARIANO, E. B; ALMEIDA, M. R; REBELATTO, D. A. Princípios básicos para uma proposta de ensino sobre análise por envoltório de dados. In: XXXIV COBENGE, 2006.

MARTINS, M; LARISSA, M; HIRASSAKA, S. Análise das demonstrações financeiras: estudo de caso da Kroton educacional s/a do período de 2015 a 2017. Observatorio de la Economía Latinoamericana, n. agosto, 2018.

MATARAZZO, D. C. ANÁLISE FINANCEIRA DE BALANÇOS: Abordagem Gerencial. 7. ed. São Paulo: Atlas, 2010. 
MEDEIROS, F. S. B. et al. Gestão econômica e financeira: a aplicação de indicadores. In: Simpósio em Excelência em Gestão e Tecnologia, 2012.

MOREIRA, M. A; DE MELO, E. A. Diagnóstico e análise para a implementação do modelo PMS em uma indústria calçadista. Revista Contemporânea de Contabilidade, Florianópolis, v. 14, n. 32, p. 157-173, 2017.

MOTA, A. F; COELHO, A. C. D; QUEIROZ, L. L. " Teorias da Informação" e Teoria da Contabilidade: contribuição para tratamento da informação contábil. In: Anais do Congresso USP de Contabilidade e Controladoria. São Paulo, São Paulo, Brasil, XVI. 2014.

OLIVEIRA, A. A. de; SILVA, A. R. da; ZUCCARI, S. M. de. P. A Análise das Demonstrações Contábeis e sua Importância para Evidenciar a Situação Econômica e Financeira das Organizações. Revista Eletrônica Gestão e Negócios, v. 1, n. 1, p.1-13, 2010.

ONUSIC, L. M; CASA NOVA, S. P. de C; ALMEIDA, F. C. de. Modelos de previsão de insolvência utilizando a análise por envoltória de dados: aplicação a empresas brasileiras. Revista de Administração Contemporânea, [s.I.], v. 11, n. 2, p. 77-97, 2007.

PADOVEZE, C. L. Controladoria Estratégica e Operacional. 3. ed. São Paulo: Cengage Learning, 2015.

PASSOS, Q. C. dos. A importância da contabilidade no processo de tomada de decisão nas empresas. 2010.

PATERSON, B. L.; BOTTORFF, J. L.; HEWAT, R. Blending observational methods: possibilities, strategies and challenges. International Journal of Qualitative Methods, v. 2, n. 1, p. 29-38, 2003. 
PEÑA, C. R. Um modelo de avaliação da eficiência da administração pública através do método análise envoltória de dados (DEA). Revista de Administração Contemporânea, v. 12, n. 1, p. 83-106, 2008.

PÉRICO, A. E; REBELATTO, D. A. do. N; SANTANA, N. B. Eficiência bancária: os maiores bancos são os mais eficientes? Uma análise por envoltória de dados. Gestão \& Produção, v. 15, n. 2, p. 421-431, 2008.

PIMENTEL, C. J. S; ALMEIDA, J. B. de. F. Análise de Envoltório de Dados (DEA) e diagnóstico empresarial pelo sistema de gerenciamento de desempenho (PMS) como instrumento de tomada de decisão na empresa "Y". TCC em Administração - Universidade Federal Rural da Amazônia, Capanema, 2019.

REIS, A. C. R. Demonstrações contábeis. São Paulo: Editora Saraiva, 2017.

RODRIGUES, T. R. Análise das demonstrações contábeis: uma contribuição no ramo de supermercado. Monografia em Ciências Contábeis - Faculdade de Ciências Contábeis e Administração do Vale do Juruena, Juína, 2009.

RODRIGUES, D. dos. S. et al. A importância da análise dos índices econômicos financeiros nas demonstrações contábeis como ferramenta de gestão para a tomada de decisão empresarial-aplicável à empresa Ok Rent a Car do segmento de serviços2011-2013". Revista Caribeña de Ciencias Sociales, 2015.

SALVADOR, C. S. A análise das demonstrações contábeis como ferramenta auxiliar para o gestor no momento da toma de decisões em uma empresa do setor vinícola de Flores da Cunha - RS. TCC (Graduação) - Curso de Bacharel em Ciências Contábeis, Universidade de Caxias do Sul., Caxias do Sul, 2011.

SANTOS, A. dos; CASA NOVA, S. P. de. C. PROPOSTA DE UM MODELO ESTRUTURADO DE ANÁLISE DE DEMONSTRAÇÕES CONTÁBEIS. RaeEletrônica, São Paulo, v. 4, n. 1, p.1-27, 2005. 
SEIFORD, L. M. Data envelopment analysis: The evolution of the state of the art (1978-1995). Journal of Productivity Analysis, v.7, p. 99-137, 1996.

SILVA, J. O. da. et al. Capacidade Preditiva de Modelos de Insolvência: com base em Números Contábeis e Dados Descritivos. In: XXVI Simpósio de Gestão da Inovação Tecnológica, 2010.

SILVA, A. A. da. ESTRUTURA, ANÁLISE E INTERPRETAÇÃO DAS DEMONSTRAÇÕES CONTÁBEIS. 4. ed. São Paulo: Atlas, 2014.

SILVA, J. M. dos. S. Desempenho de empresas brasileiras de aviação civil: uma análise das relações entre indicadores financeiros e não financeiros. Dissertação de Mestrado em Engenharia da Produção e Sistemas - Universidade do Vale do Rio dos Sinos, São Leopoldo, 2016.

SILVA, S. R. et al. A Contribuição das demonstrações contábeis no processo de concessão de crédito: um estudo de caso do município de São Paulo. REMIPERevista de Micro e Pequenas Empresas e Empreendedorismo da Fatec Osasco, v. 2, n. 2, p. 222-249, 2016.

TEIXEIRA, E. A; NOSSA, V; FUNCHAL, B. O índice de sustentabilidade empresarial (ISE) e os impactos no endividamento e na percepção de risco. Revista Contabilidade \& Finanças, v. 22, n. 55, p. 29-44, 2011.

VASCONCELOS, Y. L. et al. PESQUISA QUALITATIVA NA CONTABILIDADE GERENCIAL: uma análise sistemática metodológica. In: XX SEMEAD Seminários em Administração, 2017.

VILELA, D. L. Utilização do método Análise Envoltório de Dados Para Avaliação do Desempenho Econômico de Coorporativas de Crédito. Dissertação de Mestrado em Engenharia de Produção - Escola de Engenharia de São Carlos Universidade de São Paulo, São Carlos, 2004.

Enviado: Setembro, 2019. 
Aprovado: Outubro, 2019. 